\title{
The Impact of Information and Communication Technology Adoption on Multinational Firm Boundary Decisions
}

\author{
by \\ Wenjie Chen \\ George Washington University
}

\author{
Fariha Kamal \\ U.S. Census Bureau
}

CES 16-01 January, 2016

The research program of the Center for Economic Studies (CES) produces a wide range of economic analyses to improve the statistical programs of the U.S. Census Bureau. Many of these analyses take the form of CES research papers. The papers have not undergone the review accorded Census Bureau publications and no endorsement should be inferred. Any opinions and conclusions expressed herein are those of the author(s) and do not necessarily represent the views of the U.S. Census Bureau. All results have been reviewed to ensure that no confidential information is disclosed. Republication in whole or part must be cleared with the authors.

To obtain information about the series, see www.census.gov/ces or contact Fariha Kamal, Editor, Discussion Papers, U.S. Census Bureau, Center for Economic Studies 2K132B, 4600 Silver Hill Road, Washington, DC 20233, CES.Papers.List@census.gov. To subscribe to the series, please click here. 


\begin{abstract}
This paper evaluates the effect of adopting internet-enabled information and communication technology (ICT) adoption on the decision to reorganize production across national borders (foreign boundary decision) by multinational enterprises (MNE). Using a transaction cost framework, we argue that ICT adoption influences foreign boundary decisions by lowering coordination costs both internally and externally for the firm. We propose that the heterogeneity in the technology's characteristics, namely complexity and the production processes' degree of codifiability, moderate this influence. Using a difference-in-differences methodology and exploiting the richness of confidential U.S. Census Bureau microdata, we find that overall ICT adoption is positively associated with greater likelihood of in-house production, as measured by increases in intra-firm trade shares. Furthermore, we find that more complex forms of ICT are associated with larger increases in intra-firm trade shares. Finally, our results indicate that MNEs in industries in which production specifications are more easily codified in an electronic format are less likely to engage in intra-firm relative to arms-length trade following ICT adoption.
\end{abstract}

\footnotetext{
* Any opinions and conclusions expressed herein are those of the author(s) and do not necessarily represent the views of the U.S. Census Bureau. All results have been reviewed to ensure that no confidential information is disclosed. We thank the Special Issue Editors Juan Alcacer, John Cantwell, and Lucia Piscitello, as well as four anonymous reviewers, for their helpful comments. We are especially indebted to comments by Rene Belderbos, Alvaro Cuervo-Cazurra, Jose de la Torre, Susan Feinberg, Cheryl Grim, Anupama Phene, and Nikolas Zolas that have greatly helped in shaping this paper. We also thank participants at the JIBS Special Issue conference and at the 2014 Academy of International Business Annual Meeting for useful comments and suggestions. Chen thanks the Institute for International Economic Policy at GWU for financial support. All errors remain our own.
} 


\section{INTRODUCTION}

Profound innovations in information and communication technologies (ICT) during the last three decades have reshaped the global landscape in which firms operate. The emergence of these technologies has enabled firms to reduce transactions costs, including those in transportation, communication, and coordination. Multinational enterprises (MNEs), in particular, have benefited from the innovations in ICT and have adopted them into their operations and international production processes. This in turn has influenced increasingly complex firm boundary decisions.

The transaction cost theory has been the leading paradigm in the analysis of the multinational firm, particularly, to answer the question of whether or not to undertake an activity within a firm's own boundaries (Buckley \& Casson, 1976, 1998, 2009; Dunning, 1980; Hennart, 1982, 2009; Teece, 1985). Under this conceptual framework firms choose over alternative governance structures in order to minimize transaction costs. By using ICT, MNEs are able to mitigate transaction costs that might alter the decision between in-house production versus arm’s length exchange. Forman and McElheran (2012) study the effect of ICT adoption on the domestic boundary choices of firms by examining changes in the share of total shipments that are transferred internally within domestic firms in the United States. In contrast, Fort (2013) primarily focuses on the effect of ICT on domestic versus foreign sourcing decisions, thus, highlighting the spatial location choice of the firm. Our study complements these existing studies by analyzing the role of ICT adoption in shaping the decision between how much is produced within and outside the boundaries of the firm across national borders, henceforth referred to as a firm's foreign boundary decision.

We examine ICT's impact on a firm's foreign boundary decision to make or buy through the lens of the firm's intra- and inter-firm trade choices, explicitly assuming that the firm has decided on foreign production. We propose that from the viewpoint of the firm, ICT adoption lowers both internal and external coordination costs ex post through two independent effects: (1) lowering of communication and search costs (Malone, Yates, \& Benjamin, 1987), and (2) lowering of economic incentive costs in terms of economic moral hazards and opportunistic behavior (Clemens, Reddi, \& Row, 1993; Gurbaxani \& 
Whang, 1991). The efficient mix of a firm's in-house and arm's length production is determined by trading off external and internal coordination costs. We argue that this baseline effect of ICT on intra-firm relative to arms-length production is theoretically ambiguous and hence ultimately an empirical question.

Most existing studies - with the exception of Feinberg and Keane (2006) and Keane and Feinberg (2007) - in the area of ICT and firm organization have generally concentrated on the net effect of the impacts of ICT adoption on firm boundary decision, i.e., either increased in-house production or increased arms-length production. De la Torre \& Moxon (2001) provide an excellent overview of the literature pertaining to the same time period, the early nineties, as the focus in our study. Rangan and Sengul (2009) find that MNEs in industries with higher ICT investment intensity exhibit lower propensity for transnational integration. Dosi, Gambardella, Grazzi, and Orsenigo (2008) provide evidence on the contrary to suggest that, on balance, increased ICT investments are positively correlated with intraorganizational interactions. Both these studies capture the net effect of ICT investments on foreign boundary decisions, with the underlying premise that outsourcing and in-house production are substitutes for each other.

However, ICT affects all MNE-related production, both in-house and at arms-length, in ways that are not always mutually exclusive. In a departure from prior research, our study highlights that the choices of arms-length and intra-firm production may occur simultaneously within the same firm. For instance, in early 2000, the Swiss food and beverage multinational enterprise Nestlé invested \$1.8 billion in ICT (Worthen, 2002) ${ }^{1}$. After ICT installation, global subsidiaries exploited the new network to share price information and exert market power by acting in a coordinated manner. As a result, Nestlé reduced the number of external suppliers and procurement costs by up to 20 percent. Concurrently, Nestlé began using a new web-based system to contract with external suppliers directly. ICT installation can thus have significant effects on firms' boundary choices and as a result, its intra-firm and arms-length trading patterns.

Many studies in the organization and communication science research literature have examined the relationship between ICT and organizational structures (McPhee \& Poole, 2001; Rice \& Gattiker, 
2001), but relatively little research attention has focused on the specificity and heterogeneity of ICT systems and their distinct moderating effects on a firm's boundary decisions (notable exceptions are Keane \& Feinberg, 2007; Feinberg \& Keane, 2006; and Rangan \& Sengul, 2009). In this paper, we study the moderating role of characteristics of ICT systems. We hypothesize that the firm's intra-firm transactions relative to its arms-length transactions will increase, the greater the complexity of the type of ICT adopted. More complex types of technology require greater synchronization between adopting firm units in order to maximize the gains. Thus, ex post of the firm's decision to adopt ICT, it is more likely that more complex ICT would require using parties to have the necessary ICT infrastructure and commitment in investing and maintaining the network systems.

We further hypothesize that the firm's intra-firm transactions relative to its arms-length transactions will decrease the more readily its production process can be electronically codified. As it is easier to break up a production chain in which processes are more readily codified, each value chain link can separately benefit from ICT adoption and result in cost reductions. Thus, we would expect MNEs operating in industries where the production process is more readily codified into electronic formats to have a proclivity for arms-length relative to intra-firm transactions following ICT adoption.

We study ICT adoption in the context of globalization and increased trade integration (Antràs \& Yeaple, 2014). Our sample period (1992 and 1999) spans the advent of internet-enabled ICT and the emergence of global value chains. As internet-enabled ICT has been commercially available only since 1995 (Forman, Goldfarb, \& Greenstein, 2005), we focus on a relatively early period of internet-enabled ICT adoption. Thus, our analysis provides a valuable benchmark that can act as a baseline and lower bound on the impact of ICT adoption on MNEs' boundary decisions. We use detailed data on US manufacturers' choice of ICT adoption at the plant level for a host of different industries in the manufacturing sector using the 1999 Computer Network Use Supplement (CNUS), an addendum to the Annual Survey of Manufactures (ASM). This novel and comprehensive dataset allows us to provide a nuanced picture of the role of ICT adoption on MNE boundary decisions and unlike most existing studies, we are able to exploit the heterogeneity of the disaggregated data in terms of various types of ICT 
adoption. We measure MNE's foreign boundary choices through its intra-firm and arms-length trade transactions obtained from the Longitudinal Foreign Trade Transactions Database.

We find robust empirical support for our hypotheses. Overall, ICT adoption enhances withinfirm boundary transactions as measured by increased intra-firm trade shares. By using a difference-indifferences identification strategy and contrasting pre- and post-ICT adoption periods, results show that firms with more sophisticated types of ICT experience increases in intra-firm relative to arms-length trade transactions. We also confirm our expectation that following the adoption of ICT, firms in industries where production processes are more readily codified into electronic formats experience decreases in intra-firm trade shares. Our baseline results are robust to construction of alternative samples and controls for simultaneity bias. We consider two distinct samples - single-plant firms only and single-plant and multi-plant firms where all its plants either adopt or do not adopt ICT. We address the simultaneity bias that arises if firms are proactively adopting ICT in anticipation of enhancing intra-firm or arms-length trade. We re-estimate our baseline specification controlling for a firm's prior use of proprietary network technology.

Our examination of the role of ICT on a firm's foreign boundary decisions makes a theoretical and empirical contribution to the existing literature on ICT and firm organizational choices. Although there is a growing literature on the role of fragmentation and offshore production, where technological improvements play an essential role (Jones \& Kierzkowski, 2001; Deardorff, 2001; Kohler, 2004; Antràs, Rossi-Hansberg, \& Garicano, 2008; Grossman \& Rossi-Hansberg, 2008; Costinot, Vogel, \& Wang, 2013), the theoretical and empirical analyses rely on the assumption that firms have already upgraded their technology in order to facilitate production fragmentation. Our theoretical and empirical focus is exactly on the effect of a firm's decision to adopt ICT on its foreign boundary choices. We build on the work of Rangan and Sengul (2009) by extending the theoretical model to include more detailed types of ICT applications and the moderating effects of characteristics of ICT on a firm's international boundary decisions. Our work also relates to and extends the study by Feinberg and Keane (2006), which finds that technology, measured as the residual from a structural model, is an important factor in intra-firm trade by 
multinationals between the U.S. and Canada. Whereas Rangan and Sengul (2009) and Cho (1990) employ data aggregated at the industry level, our analysis uses a direct plant-level measure of ICT and provides evidence of a link between specific types of ICT adoption and a firm's international boundary decision.

The advent of ICT has been accompanied by increased formation of global value chains that are creating new opportunities for firms to become more globally integrated, which has been associated with growth (Baldwin \& Lopez-Gonzales, 2014). Thus, it is important for policy makers to understand how new avenues linking them to global production chains can be exploited. Because MNEs are a central feature of global production networks mediating 80 percent of global trade (UNCTAD, 2013), understanding how ICT reshapes multinational firms' global activities is an important avenue of scholarly investigation.

The following section develops our hypotheses grounded in transaction cost theory. Section 3 describes the data sources and variable construction, section 4 describes our empirical methodology, section 5 presents the results, and section 6 provides discussion and conclusion.

\section{Hypotheses Development}

\subsection{Transaction Costs and ICT Adoption}

An MNE has to communicate with, coordinate, search for and monitor cross-border operations. Broadly speaking, a firm's coordination costs can be divided into two distinct categories: internal coordination costs and external coordination costs (Kim \& Mahoney, 2006). Internal coordination costs represent the economic costs incurred for communications, data transfer, and other economic expenditures on managing dependencies between activities within a firm. External coordination costs represent the economic costs of locating suppliers, writing contracts, and other economic costs of market procurement.

The internalization literature has highlighted the opposing nature of the outsource/offshore versus producing in-house decision yielding divergent findings. On the one hand, the adoption of ICT can reduce the economic costs of internal coordination within the firm by improving the quality and speed of 
information processing and management's decision making. Moreover, by adopting ICT, management can reduce agency costs through improved monitoring and evaluation systems. Bloom, Garicano, Sadun, and Van Reenen (2014) find that adoption of ICT within the same organization can reduce communication costs as well as knowledge acquisition costs. Moreover, Dosi et al. (2008) find that the size-distribution of firms and industrial concentration in the advanced economies over the past few decades have not changed despite the increasing role of ICT. They deduce that intra-organizational interactions still dominate over market interactions, contradicting the notion that there has been a significant movement toward market coordination due to ICT. Along the same lines, other studies have also found greater internalization effects of ICT (Brynjolfsson, 1994; Gurbaxani \& Whang, 1991; Zenger \& Hesterly, 1997). Thus, ICT adoption can reduce internal coordination costs and provide management with the capability to manage an organization more effectively and facilitate increased integration.

On the other hand, adoption of ICT can directly reduce market transaction costs by providing a cost-effective means to access and process market information, thus, reducing external coordination costs to the firm. ICT can also reduce market transaction costs by facilitating closer inter-firm links through information sharing and mutual monitoring. Rangan and Sengul (2009), for instance, argue and provide empirical evidence for increased internationalization at arm's length associated with increased ICT spending. Hitt (1999) observes that an increased use of IT systems is associated with a substantial decrease in vertical integration, and suggests that the empirical evidence points to the effect of IT systems lowering external coordination costs more than internal coordination costs. Malone et al. (1987) propose that ICT can lead to an overall decline in coordination costs in terms of searching and communicating with external transacting parties. Both Gurbaxani and Whang (1991) and Clemens et al. (1993) argue that the usage of ICT can reduce transaction risks such as the contractual hazards of shirking and opportunism through improved monitoring and reduced specificity in coordination with external partners. Thus, ICT systems can reduce external coordination costs and encourage outsourcing.

Given these simultaneous channels whereby ICT can reduce costs for both external and internal transactions, Gurbaxani and Whang (1991) aptly note that 'the net effect of IT on firm size varies from 
situation to situation, depending on the cost structure of the firm and the modes of synergy generated by integration.' Hence, the net effects are theoretically ambiguous and we rely on empirical evidence to guide us.

Thus far, we have abstracted from heterogeneity in types of ICT as well as differences across industries in the application of ICT. In the following sections, we develop two testable hypotheses. First, we address the adoption of different types of ICT and how it moderates the effect of a firm's choice in internal versus external forms of transactions. Second, we examine how exogenous industry characteristics influence firm's boundary choices through the use of ICT.

\subsection{Complexity of ICT}

ICT systems vary widely in terms of their complexity and sophistication and with them, the level of investment that is required of the firm to undertake. Complex types of ICT, enatiling relation-specific investments and high sunk costs, often requires the firm to incur additional costs of coordination among adopting firm units. We note here that a priori, it is not clear, what type of firm would be more prone to adopt complex types of ICT, and it is not the focus of our study. Existing research shows that the costs to adopt business process innovations are variable depending on the mix between internal and external adjustment costs that are firm specific (McElheran, 2015). She describes that the amount of complementary adjustment needed to adapt to new innovations involving "new processes, supporting organizational structures and enabling ICT was difficult to predict and varied widely by firm and by the type of business process innovation they were pursuing.” Our argument is that in order to be effective ex post, however, the adoption of firm-specific ICT requires matching investments for co-specialization with other firm-specific resources, such as ICT-trained employees or ICT-supported distribution network. Furthermore, ex post of adoption, more complex types of ICT that have features of enhancing coordination and information sharing would becomeess valuable if the partnering units' ICT systems are not compatible.

Even after adoption of ICT, more complex types of ICT requires coordinated effort between transacting parties for optimizing the benefits. Moreover, complexity may lead to increased 
interdependence between transacting parties due to the need to implement similar customization of technology. Thus, given that firms have already adopted ICT, it is more likely that higher degree of complexity in the ICT is associated with more internal integration in order to ensure maximization of benefits from ICT adoption. Thus, we hypothesize the following:

Hypothesis 1: All else being equal, the more complex the type of ICT adopted, the more likely it is to facilitate increased integration between internal firm units.

\subsection{Electronic Codifiablity of the Production Process}

Industry characteristics may influence the scope and nature of the impacts of ICT adoption on a firm's internal versus external integration. One of the main barriers to externalization is the noncodifiable nature of tasks and production specifications along with specific customization requirements of the product. Industries in which the production process lends itself to fragmentation would benefit from the adoption of ICT in locating the lowest cost producers for each chain of its various production stages. For certain industries, for instance, Sturgeon (2002) describes how production processes are broken down into distinct value chains, whereby linkages are achieved between the chains via the transfer of codified information.

Technological innovations in manufacturing processes, such as the introduction of computeraided design (CAD) and computer-aided engineering (CAE) software, have made it possible for the firm to translate manufacturing designs and specifications into electronic formats, and share production requirements and designs (Fort, 2013) with other firms. For firms in these industries that are able to make use of $\mathrm{CAD}$ and $\mathrm{CAE}$ technologies to break up their production into smaller and simpler tasks by codifying product specifications, it is possible to minimize leakage of crucial proprietary knowledge by choosing to outsource certain intermediate input production to external suppliers and maintain in-house the production of intermediates that have higher intellectual property content. From an external supplier's viewpoint, the codifying process addresses hold-up problems by reducing the cost of customization significantly, resulting in greater diversification of the supplier's risk and reducing costs of being a "holdup hostage” to each buying firm. Then, ICT adoption in industries where the production process is easily 
codified into electronic formats, eases the outsourcing process by finding the lowest cost producer in the market place. We propose the following:

Hypothesis 2: All else being equal, the higher the degree of electronic codifiability of the production process of the MNE's industry, the more likely it is to experience increased outsourcing following ICT adoption.

\section{Data}

\subsection{Sample}

We use four confidential micro datasets sourced from the U.S. Census Bureau - Annual Survey of Manufactures that includes the Computer Network Use Supplement, Census of Manufactures, Longitudinal Foreign Trade Transactions Database, and the Longitudinal Business Database - in order to carry out the analysis. In what follows below, we describe the steps to construct our analysis dataset and then in Section 3.2 we describe our variables of interest in detail.

ICT data. In order to measure information and communication technology adoption within a firm, we utilize the 1999 survey addendum to the U.S. Census’s Annual Survey of Manufacturers called the Computer Network Use Supplement. The CNUS is a unique dataset due to its wealth of detail on the firm's networking technologies at the plant level and its national representativeness as an addendum to a legally required Census survey. The survey was intended primarily to measure electronic commerce (ecommerce) over computer-mediated networks (Messenbourg, 2001). Our measure of ICT captures computer networking technologies that can be used to communicate with and share information between both internal and external parties, and is therefore ideally suited for our analyses. In particular, we use the first question in the CNUS that asks if the responding establishment uses various types of computer networks: internet, intranet, extranet, Local Area Network (LAN), Electronic Data Exchange (EDI). The associated variables in the survey data are separate indicator variables that take on a value 1 if the plant uses any one of these types of networks, and 0 otherwise. We use the first four indicator variables to create an overall ICT measure, described shortly. 
We consider LAN, internet, intranet, and extranet as internet-enabled network technologies since these technologies accompanied the commercialization of the internet and therefore would have been unlikely to have diffused widely prior to 1995 . We utilize the information if a firm uses EDI in robustness checks as a control for the existence of previous network technology. The CNUS sample consists of about 38,000 plants belonging to about 22,000 firms; together, they account for more than half of manufacturing employment and output in the U.S. at the time (U.S. Census Bureau, 1999).

Intra-firm trade transactions data. We link the computer network data to a firm's international merchandise trade transactions in the Longitudinal Foreign Trade Transactions Database (LFTTD). We focus on intra-firm trade shares because of the absence of detailed plant-level trade data in the annual surveys or censuses of manufacturing. The LFTTD is a transaction-firm linked database linking the universe of individual merchandise trade transactions, both exports and imports, to the U.S. firms that make them. We use information on the value, date of transaction, and the categorical variable that indicates whether a trade transaction took place between related parties or not. Exporting parties are related when either owns ten percent or more of the other party, whereas for imports, the threshold for related party is five percent under United States Code 19, §1401a(g). Ruhl (2013) discusses the comparability of the intra-firm trade measure derived from merchandise trade transactions data compared to that derived from Bureau of Economic Analysis surveys and finds them mostly similar. The related party variable has previously been used to identify multinational activity by Bernard, Jensen, \& Schott (2009) and Nunn \& Trefler (2013) among others.

We first select firms in the LFTTD that are present in both 1992 and 1999, since we adopt a difference-in-differences methodology requiring us to follow changes in intra-firm trade shares within a firm between two time periods. Then we merge the resulting dataset to the CNUS data. The CNUS data is first aggregated at the firm level prior to the merge, and we describe the details of the aggregation method below. We further restrict our analysis sample to firms that operate in the manufacturing sector, since CNUS was sent to manufacturing establishments only. Using the Longitudinal Business Database (LBD), which consists of data on all existing establishments that have at least one paid employee in the U.S. non- 
farm, private economy (Jarmin \& Miranda, 2002), we identify the primary two-digit sector manufacturing, retail, wholesale trade, or others - in which a firm operates. Since multi-unit firms may operate in several sectors of the economy, the firm is considered to be operating in the sector that houses the largest share of its total employment. We find that $94 \%$ of all firms in the merged LFTTD and CNUS datasets operate in the manufacturing sector. This results in our analysis sample of 5,850 unique firms that engaged in international trade - related party, unrelated party, or both - in 1992 and 1999.

\subsection{Measures}

\section{Dependent variable.}

Since we are interested in the firm's make or buy decisions across international borders, we operationalize the foreign boundary choice of MNEs between in-house and arm's length production by utilizing information on (i) intra-firm trade between U.S. parents and their foreign affiliates as well as between foreign-controlled U.S. affiliates and their foreign parent groups; and (ii) inter-firm trade between U.S. parents and other non-affiliated parties as well as between U.S. affiliates of foreign parents and other non-affiliated parties. ${ }^{2}$ Specifically, the dependent variable is the change in intra-firm trade as a share of total trade value at the firm level between 1992 and 1999. We construct intra-firm trade shares using both import and export transactions in the LFTTD. The numerator is the sum of total exports and imports of the firm that are conducted between related parties, and the denominator is the sum of total exports and imports that the firm conducts between both related and unrelated parties. Our proposed measure allows us to contrast intra-firm and arms-length trade flows (Hipple, 1990). In particular, it is measured in levels as:

$$
I F_{i t}=\left(\text { Exports }_{i r t}+\text { Imports }_{\text {irt }}\right) /\left(\text { Exports }_{i t}+\text { Imports }_{i t}\right) \text {, }
$$

where $i$ indexes firm, $r$ related party, and $t$ year. The variable used in our empirical specification is therefore given by,

$$
\Delta I F_{i}=I F_{i, 1999}-I F_{i, 1992}
$$

Note that our explicit assumption here is that the firm has already made a decision whether or not to engage in foreign production. We do not model the decision of a firm to become a multinational. 
Independent variables. Our explanatory variable of interest is a firm-level measure of ICT adoption, $I C T_{i t}$, bounded between 0 and 1 . We first create an indicator variable, Network $k_{j t}$, that takes on a value 1 if plant $j$ has any one of the target types of internet-enabled computer networks - the internet, local area network (LAN), intranet, or extranet - and 0 otherwise. This variable takes on a value of 0 for all plants in 1992 following the assumption of little or no diffusion of internet-enabled ICT pre-1995. Since none, few, or all of the plants belonging to a firm may adopt ICT, in order to create a firm level measure of ICT adoption, we weigh this indicator variable by the plant's share in total firm employment as follows:

$$
\text { ICT }_{i, 1999}=\sum_{j=1}^{n}\left(\text { Employment }_{j, 1999} / \text { Employment }_{i, 1999}\right) * \text { Network }_{j, 1999}
$$

where $j$ indexes manufacturing plants belonging to firm $i$, and a firm may have $n$ number of plants. For a single-plant firm and multi-plant firm where all its plants adopt an internet-enabled network technology, the employment weight is one. Approximately, 85 percent of the firms in our analysis sample are multiplant firms, and in about half of these firms, some but not all of their plants adopt a network technology. Therefore, we create an employment weighted measure of network adoption at the firm level. We also carry out robustness checks to ensure that our results are not being driven by this particular weighting scheme. In particular, we re-run our base specification on a sample of single-plant firms only as well as multi-plant firms where all of the plants belonging to the firm adopt ICT. Finally, our dependent variable of interest, assuming all plants in 1992 had not adopted internet-enabled ICT, is as follows,

$$
\Delta I C T_{i}=I C T_{i, 1999}
$$

In order to evaluate hypothesis 1, we appeal to Forman (2005) in ranking the various types of networking technologies as simple or more complex. Forman (2005) considers basic internet access as simple while complex technologies include business-to-customer and business-to-business e-commerce. Following this logic, we rank the computer networks reported in CNUS in ascending order of complexity as internet and all other internet applications for e-commerce, namely, LAN, intranet, and extranet. Internet $_{i t}$ is measured as in (1.3) where Network $_{j t}$ takes on a value 1 if a plant chose internet as the 
type of network used as indicated in question 1. We create similar measures as in (1.3) for LAN, intranet, and extranet separately. Then we create an indicator variable, $E$ - commerce Applications $s_{i t}$, that takes on a value of 1 if a firm has any of the following - LAN, intranet, or extranet - and 0 otherwise. Finally, we have our measures of interest similar to (1.4) as $\Delta$ Internet $_{i}$ and $\Delta E-$ commerce Applications $_{i}$, respectively.

Although internet is the largest computer network by definition, because of its global scope, it cannot be customized by the firm. The other three types of networks allow restricted access to various parties depending on the firm's goals. LAN is a private network that links computers at a single location, such as at an office building. Intranets and extranets are both far more complex than LAN. Extranets allow controlled access - typically to customers or suppliers but also to geographically dispersed divisions of a company - from outside of an organization's intranet. We consider the internet as the simplest type of network since no particular control or access infrastructure are required, while the rest are increasingly more complex in their configurations relative to the internet.

To assess the degree of electronic codifiability of the production process in industry $k$, Codifiability $_{k}$, we calculate the fraction of plants in a six-digit North American Industrial Classification System (NAICS) industry that used integrated Computer Aided Design or Computer Aided Engineering (CAD/CAE) business processes in 1999. Therefore, this measure does not vary over time. We utilize question 7, part c, number 1 , in the CNUS to construct the share of plants in an industry that uses CAD/CAE relative to plants that did not use CAD/CAE and had no plans to use it by 2002, following Fort (2013). Both CAD and CAE are computer-aided processes that may be used to translate manufacturing designs and specifications into electronic formats. Therefore, Codifiability , measures the intensity of CAD/CAE use in an industry and captures the relative degree to which industry production processes can be fragmented and codified into electronic formats.

Control variables. We additionally include firm specific variables of age as of 1992, Initial Age , $_{\text {, }}$ and change in labor productivity between 1999 and 1992, $\Delta$ Labor Productivity $_{i}$, to control for 
experience and productivity of the firm. We obtain information on firm age from the LBD. For firms with multiple plants, age is calculated as the difference between the year of interest and the year of establishment of its oldest plant. We consider age as of 1992, since in our difference-in-differences specification, the change in age will be a constant seven years for all firms. Labor productivity is measured as total value of shipments per employee and we measure the change between 1992 and 1999. Firm-level measures of shipments and employment are constructed as the sum of these respective variables over all plants belonging to the firm. The plant level data on the value of shipments and employment in 1992 and 1999 is sourced from the 1992 Census of Manufactures and the 1999 ASM, respectively.

Table 1 provides summary statistics of all our main variables in 1992 and 1999 . We can see that about $67 \%$ of the firms in our sample adopt ICT. This share varies by the various types of ICT. About $57 \%$ of the firms adopt the internet, while a larger share, 85\%, adopt the LAN, intranet, and/or extranet. The table also provides the average intra-firm trade shares further differentiated by exports and imports. We see that in 1992, $13 \%$ of total trade is intra-firm in nature for an average firm in our sample with about an even split between intra-firm exports and imports. This share rises to over $14 \%$ by 1999 . Finally, average age as of 1992 of a firm in our sample is about 13 years and average labor productivity increases from \$159,000 per employee to \$224,000 per employee between 1992 and 1999.

[insert Table 1 about here]

\section{Econometric Model}

We use a fixed effects panel data model as in Forman and McElheran (2012), thus implementing a difference-in-differences identification strategy. We have a simple set-up with two time periods, 1992 and 1999, and two distinct groups of firms, those that adopt ICT (treated firms) and those that do not (control firms). We compare the share of intra-firm trade in overall trade prior to adoption of ICT to the share after adoption, and relative to those that do not adopt ICT. Thus, the first difference is the difference in intra-firm trade shares between 1992 and 1999 and the second being the difference between ICT adopters and non-adopters. Our key identification assumption is that diffusion of internet-enabled 
information and communication technology was not widespread among firms prior to 1995 (Forman et al., 2005). Therefore, we choose the earliest year for which trade data is available as the pre-period, 1992, at which time all firms, following previous studies (Forman et al., 2005; Forman \& van Zeebroeck, 2012), are assumed to have no or narrowly diffused internet-enabled ICT technology.

Our empirical approach removes firm-level time-invariant characteristics that may be correlated with both ICT adoption and intra-firm trade shares. However, time-varying firm characteristics such as productivity may influence the decisions to simultaneously engage in intra-firm trade and adopt ICT. We include controls for firm productivity and age to address such concerns about omitted variables. Since we estimate a two period difference-in-differences model, we implement the following regression equation:

$$
\Delta I F_{i}=\beta_{1} \Delta I C T_{i}+\beta_{2} \Delta \text { Labor Productivity }+\beta_{3} \text { Initial Age }_{i, 1992}+\Delta \varepsilon_{i},
$$

where $\Delta$ denotes change between $t$ and $t-1$ such that $\Delta I F_{i}=I F_{i, 1999}-I F_{i, 1992}$ represents change in intrafirm trade shares between 1999 and 1992 and similarly for the explanatory variables. We rely on the data to reveal the sign of $\beta_{1}$.

For testing hypothesis 1 , we separately include specific measures of ICT, i.e., $\Delta$ Internet $_{i}$ and $\Delta$ E-commerce Applications $_{i}$ as follows:

$$
\begin{aligned}
& \Delta I F_{i}=\beta_{1} \Delta \text { Internet }_{i}+\beta_{2} \Delta \text { Labor Productivity }_{i}+\beta_{3} \text { Initial Age }_{i, 1992}+\Delta \varepsilon_{i}, \\
& \Delta I F_{i}=\beta_{1} \Delta \text { Ecommerce }_{i}+\beta_{2} \Delta \text { Labor Productivity }_{i}+\beta_{3} \text { Initial Age }_{i, 1992}+\Delta \varepsilon_{i},
\end{aligned}
$$

Abstracting from the initial decision of whether or not to adopt ICT, the ability to maximize the benefits of having complex ICT systems would be easier between two parties that have more integration and coordination, and thus favor in-house production, which should be reflected in increased intra-firm transactions relative to arm's length. Thus, we hypothesize that the sign of $\beta_{1}$ will be larger in equation (1.6b) compared to equation (1.6a).

To assess hypothesis 2, the extent to which the impact of ICT on intra-firm trade shares varies in industries with varying degrees of electronic codifiability, i.e. propensity to codify product specifications 
in an electronic format, and thus easily communicate with parties in foreign locations, we run the following specification:

$$
\begin{gathered}
\Delta I F_{i}=\beta_{1} \Delta I C T_{i}+\beta_{2} \Delta I C T_{i} * \text { Codifiability }_{k} \\
+\beta_{3} \Delta \text { Labor Productivity }_{i}+\beta_{4} \text { Initial Age }_{i, 1992}+\Delta \varepsilon_{i},
\end{gathered}
$$

where the industry codifiability measure is constructed based on the fraction of plants in an industry, $k$, that used CAD/CAE software in their production process in 1999. Our interest is in the interaction term and we expect $\beta_{2}$ to be negative.

\section{Results}

\section{1 Baseline Results}

Table 2 presents a correlation matrix of the main variables over our sample period. Since we employ changes over time in our empirical specifications, we provide correlations between the change measure of a variable rather than in levels, except for initial firm age that is calculated as of 1992. We find that ICT and each of its types separately are positively and statistically significantly correlated with changes in intra-firm trade shares. The overall ICT adoption measure is highly correlated with the adoption of the internet and other e-commerce applications. This is not surprising given that our overall ICT measure is comprised of the internet, LAN, intranet, and extranet.

\section{[insert Table 2 about here]}

In Table 3 we present regression results to examine the net effect of ICT on MNE foreign boundary choices. The estimates reported in the tables reflect the average difference in intra-firm trade shares between ICT adopters and non-adopters, net the initial difference in the pre-period. The first column of table 3 displays results from specification (1.5). We see that overall ICT adoption at the firm level is associated with a 1.8 percentage point increase in intra-firm trade shares compared to those MNEs that do not adopt ICT, net of the difference in the initial period. Our result suggests that, for MNEs operating in the U.S. manufacturing sector, ICT-induced internal cost reductions outweigh external cost reductions, thus, favoring internal cross-border transactions over external ones.

To test hypothesis 1, we consider various types of ICT separately in columns 2 and 3 following 
specifications (1.6a) and (1.6b), respectively. We find that more complex internet-enabled ICT tends to have a larger impact on internal cross-border transactions, as exhibited by increased intra-firm trade shares. In order to compare the magnitudes of the coefficients on our internet and e-commerce application variables, we compute and report beta coefficients. Beta coefficients refer to how many standard deviations a dependent variable will change, per standard deviation increase in the explanatory variable, thereby allowing us to compare the magnitude of coefficients across different regression specifications. We find that the beta coefficient on the internet variable is 0.026 while on the e-commerce applications variable is 0.032 . This implies that a one standard deviation change in internet use is associated with an increase of 0.026 in intra-firm trade shares, while the increase is 0.032 when considering e-commerce applications. These findings together provide support for hypothesis 1, in that more complicated forms of ICT adoption that require simultaneous investments in ICT infrastructure encourage more internal firm activities, highlighted by increased trade between internal firm units relative to arms length trade.

[insert Table 3 about here]

Next, table 4 presents the results evaluating hypothesis 2 following specification (1.7). The number of firms in the analysis sample is reduced because we were not able to create a measure of electronic codifiability for every six-digit NAICS represented in our sample. As predicted, the degree of electronic codifiability in an industry dampens the impact of internet-enabled ICT adoption on intra-firm trade. Although ICT adoption itself is associated with higher intra-firm trade shares, in industries more prone to electronic codifiability of its production process, this effect is muted.

[insert Table 4 about here]

In all our specifications, the coefficients on the firm level control variables of age and labor productivity are similar. Initial firm age is negative and statistically significant implying that older firms in our sample tend to experience decreased intra-firm trade over the sample period. The coefficient on labor productivity is positive and statistically significant implying that changes in firm productivity are positively correlated with changes in intra-firm trade shares.

\subsection{Robustness Checks}


We conduct several robustness checks to further test for simultaneity bias and to check whether our results are sensitive to sample selection. In order to address concerns that firms may proactively adopt ICT in anticipation of enhancing intra-firm or arms-length trade, we re-run our baseline specification using information on a firm's use of Electronic Data Interchange (EDI). EDI is an older and proprietary network technology used to exchange documents between businesses in a standardized format. It is one of the choices of computer networks included in question 1 of the CNUS. The existence of EDI indicates prior investments in information and communication technology at a firm. As Forman (2005) finds, one of the important factors determining likelihood of internet adoption is prior network investment. We rerun our baseline results controlling for the existence of EDI that is constructed as outlined in equation (1.3) and find that results still remain quantitatively and qualitatively unchanged.

Due to the aggregation of plant level data to the firm level, the results may be influenced by the weighting mechanism that we employ. To account for that, we re-run our econometric specifications on a sample consisting of only firms that are single plant in the U.S. The reasoning here is that we are not using any weights in constructing the ICT measures, since the firm and plant is synonymous. The results are virtually identical to those using the whole sample including both multi- and single plant firms. Next, in cases where only a few plants within multi-plant firms adopt ICT, the identification of adoption versus non-adoption at the firm level is not strict. Thus, we impose a stricter definition of adoption and nonadoption, similar to considering single-unit firms only, but including only multi-plant firms where all or none of its plants adopt ICT. In this sub-sample, the explanatory variable is a purely categorical variable that takes on a value 1 when all plants within a firm adopt ICT and 0 if none of the plants within a firm adopt ICT. The results are robust to these sample variations.

It could also be the case that ICT has a stronger influence on certain functions within the firm. The CNUS includes various questions about the stage of the production process that utilizes ICT. We follow the survey's breakdown in areas of plant operation (question 7): purchasing, orders of manufactured products, production management, logistics, and communication and support services. Under each of these categories, the adoption of ICT is positive and statistically significant with respect to 
its relationship with intra-firm trade shares. The results support Keane and Feinberg's (2007) finding that improvements in logistics encouraged intra-firm trade between U.S. parents and their Canadian affiliates. Yet, more importantly, it also highlights that logistics is not the only area of production that was affected by ICT adoption and subsequently a firm's intra-firm trade patterns. We find that the adoption of ICT to carry out each of these functions has a positive effect on intra-firm trade shares.

Since we can distinguish between related party exports and related party imports in our data, we further explore the role of imports or exports in driving the overall results. To this end, we rerun the regressions using only intra-firm exports as a share of total trade, and then separately using only intrafirm imports as a share of total trade. The results again are statistically significant and similar to those using total intra-firm trade shares, suggesting that ICT adoption impacted both intra-firm exports and imports similarly. All robustness check results are available upon request.

We acknowledge that even after conducting the above-discussed robustness checks, the difference-in-differences methodology implemented in this paper may be subject to endogeneity concerns. In particular, aside from controlling for prior technology investment at a firm, we are not fully able to control for all time-varying factors that may simultaneously impact ICT adoption and intra-firm trade shares. However, in the absence of a longer panel of the CNUS or other similar surveys, we utilize this unique data to provide valuable insights into the impact of ICT adoption on foreign boundary choices for a group of early technology adopters.

\section{Discussion and Conclusions}

We analyzed the impact of ICT adoption on MNEs' foreign boundary choices. Through the lens of transactions cost theory, we argue that the choices of arms-length and intra-firm trade within the MNE are not mutually exclusive, but rather complementary. ICT can lower search and communications costs between the focal firm and both its internal and external trading partners. However, we highlight that as the complexity of the adopted ICT increases, it requires matching capabilities and mutual commitment in the trading partner's ICT adoption, hence increasing the likelihood of intra-firm trade. At the same time, ICT adoption tends to favor external transactions in industries where the production processes are readily 
translated into electronic formats. For firms operating in these industries, ICT adoption facilitates the fragmentation of production processes. This breaking up of the production process into smaller value chains allows the firm to control the extent of intellectual property shared at each stage of the production and to partner with the least cost provider at each juncture of the supply chain, thus, creating more channels of contracting with external partners. Regression results confirm our hypotheses.

Our findings contribute to two main strands of literature, that is, one on information technology and firm boundaries, and a second one on offshoring and global value chains. While the first strand has been intensively studied in the domestic context (Brynjolfsson et al., 1994; Bloom et al., 2014; Forman \& McElheran, 2012), the link to the international dimension of firm boundary has received less attention (exceptions are Feinberg \& Keane (2006), Keane \& Feinberg (2007), Rangan \& Sengul (2009)). In the burgeoning literature on offshoring and global value chains (Gereffi et al., 2005), most existing studies implicitly and explicitly make the assumption that ICT developments and adoption have contributed to the process of the slicing and dicing of the production chain. In this paper, we establish a specific link between internet-enabled ICT adoption and intra-firm trade shares. Our within firm-level measures of detailed ICT adoption and trade patterns allows analysis at a highly disaggregated level that can account for the heterogeneity in ICT adoption. Moreover, our relatively early period of study coincides with the first significant wave of internet-enabled ICT adoption (Forman et al., 2005; Forman \& van Zeebroeck, 2012) that is still the basis for many types of ICT that are being introduced today. Since these types of internet-enabled technology had just become available around that time period, our analysis provides a valuable benchmark that can act as a baseline and lower bound of the effects of ICT adoption on a firm's global production patterns. Our results also show that the propensity for fragmented production in industries favors outsourcing by firms following ICT adoption. The advent of computer-aided design and manufacturing has been proposed as an explanation for the relative intensity with which activities stay within the confines of the firm boundary and the subsequent nature of trade patterns (Helpman, 2006). Our results highlight that ICT adoption acts as a catalyst to exploit the extent to which production processes may be translated into electronic formats leading to more complex trade patterns, with the 
caveat that we focus on a sample of firms operating in the U.S. manufacturing sector.

Having highlighted the contributions of our study, we acknowledge that more remains to be done. The explicit assumption that firms have already decided on foreign production limits our results in that we focus solely on the intensive margin decision - how much does intra-firm trade change following ICT adoption. Our study is silent on the role of ICT adoption on the extensive margin decision - should a firm choose to become or cease to exist as a multinational. We are not alone, however, in making this assumption. Feinberg and Keane (2006) employ data from the Benchmark and Annual Surveys of U.S. Direct Investment Abroad administered by the BEA, which contains the population of U.S.-based MNEs, thus, by virtue of being included in this dataset, a firm must be an MNE. Rangan and Sengul (2009) make use of industry-level dataset of U.S. manufacturing MNEs in their study of ICT and transnational integration. Future studies could explore the timing of both ICT adoption and becoming an MNE.

Moreover, our sample period represents a time in which U.S. manufacturing sectors adopted major, yet basic, internet-enabled ICT advancements that changed production processes in fundamental ways. Future research examining current developments in ICT and the effect of more sophisticated technologies on firm's foreign boundary choices could build on the insights from our results. Recent developments in digital manufacturing - such as additive manufacturing, continuous manufacturing, collective manufacturing, crowdsourcing, cloud computing and cloud manufacturing, and 3D printing have revolutionized production processes and created new outlets for global value chain production. In particular, future studies could examine how specific types of ICT adoption may lead to upgrading of the global value chain and affect global value chain governance (see Gereffi et al. (2005) for a comprehensive overview of global value chain). As ICT itself is subject to constant changes and development, it would be worthwhile to assess the effects of more recent developments in ICT on MNEs' boundary choices, which we leave for future research. 


\section{References}

Antràs, P. \& Yeaple, S. R. 2014. Multinational firms and the structure of international trade. In E. Helpman, K. Rogoff, \& G. Gopinath (Eds.), Handbook of international economics: 55-130. Amsterdam: Elsevier.

Antràs, P., Rossi-Hansberg, E., \& Garicano, L. 2008. Organizing offshoring: Middle managers and communication costs. In E. Helpman, T. Verdier, \& D. Marin (Eds.), The Organization of Firms in a Global Economy, 311-39. Cambridge, MA: Harvard University Press.

Baldwin, Richard \& Javier Lopez-Gonzalez, 2014. Supply-chain trade: A portrait of global patterns and several testable hypotheses. World Economy, doi: 10.1111/twec.12189.

Bernard, A. B., Jensen, J. B., \& Schott, P. K. 2009. A portrait of firms in the U.S. that trade goods. In T. Dunne, J. B. Jensen, \& M. J. Roberts (Eds.), Producer dynamics: New evidence from micro data: 383-410. Chicago, IL: University of Chicago Press.

Bloom, N., Garicano, L., Sadun, R., \& Van Reenen, J. 2014. The distinct effects of information technology and communication technology on firm organization. Management Science, 60(12): 2859-2885.

Buckley, P. J., \& Casson, M. C. 1976. The future of the multinational enterprise. London: Macmillan.

Buckley, P. J., \& Casson, M. C. 1998. Analyzing foreign market entry strategies: Extending the internalization approach. Journal of International Business Studies, 29(3): 539-561.

Buckley, P. J., \& Casson, M. C. 2009. The internalisation theory of the multinational enterprise: A review of the progress of a research agenda after 30 years. Journal of International Business Studies, 40: $1563-1580$.

Brynjolfsson, E. 1994. Information assets, technology, and organization. Management Science, 40(12): 1645-1662.

Brynjolfsson, E., Malone, T., Gurbaxani, V., \&, Kambil, A. 1994. Does information technology lead to smaller firms? Management Science, 40(12): 1645-1662.

Cho, K. R. 1990. The role of product-specific factors in intra-firm trade of US manufacturing multinational corporations. Journal of International Business Studies, 21(2): 319-330.

Clemens, E. K., Reddi, S. P. \& Row, M.C. 1993. The impact of information technology on the organization of economic activity: The 'move to the middle' hypothesis. Journal of Management Information Systems, 10(2): 9-35.

Cuervo-Cazurra, A., \& Genc, M. 2008. Converting disadvantages into advantages: Developing country MNEs in the least developed countries. Journal of International Business Studies, 39(6): 957-979.

Costinot, A., Vogel, J., \& Wang, S. 2013. An elementary theory of global supply chains. Review of Economic Studies, 80: 109-144.

De la Torre, J., \& Moxon, R.W. 2001. Introduction to the symposium e-commerce and global 
business: The impact of the information and communication technology revolution on the conduct of international business. Journal of International Business Studies, 32(4): 617-639.

Deardorff, A. V. 2001. Fragmentation across Cones. In: S. Arndt \& H. Kierzkowski (eds) Fragmentation: New production patterns in the world economy. Oxford University Press, New York.

Dosi, G., Gambardella, A., Grazzi, M., \& Orsenigo, L. 2008. Technological revolutions and the evolution of industrial structures: Assessing the impact of new technologies upon the size and boundaries of firms. Capitalism and Society, 3(1): 1-49.

Dunning, J. H. 1980 "Toward an eclectic theory of international production: Some empirical tests.” Journal of International Business Studies, 11(1): 9-31.

Feinberg, S. E. \& Keane, M. P. 2006. Accounting for the growth of MNC-based trade using a structural model of U.S. MNCs. American Economic Review, 96(5): 1515-1558.

Forman, C. 2005. The corporate digital divide: Determinants of internet adoption. Management Science, 51(4): 641-654.

Forman, C., Goldfarb, A. \& Greenstein, S. 2005. How did location affect adoption of the commercial internet? Global village vs. urban leadership. Journal of Urban Economics, 58: 389-420.

Forman, C., \& van Zeebroeck, N. 2012. From wires to partners: How has the internet fostered R\&D collaborations within firms. Management Science, 58 (8): 1549-1568.

Forman, C., \& McElheran, K. 2012. Information technology and boundary of the firm: Evidence from plant-level data. Harvard Business School Working Paper 12-092.

Fort, T.C., 2013. Breaking up is hard to do: Why firms fragment production across locations, Working Papers 13-35, Center for Economic Studies, U.S. Census Bureau.

Gereffi, G., Humphrey, J., \& Sturgeon, T. 2005. The governance of global value chains. Review of International Political Economy, 12: 78-104.

Grossman, G., \& Rossi-Hansberg, E. 2008. Trading tasks: A simple theory of offshoring. American Economic Review, 98(5): 1978-97.

Gurbaxani, V., \& Whang, S. 1991. The impact of information systems on organizations and markets. Communications of the ACM, 59-73.

Grossman, G., \& Rossi-Hansberg, E. 2008. Trading tasks: A simple theory of offshoring. American Economic Review, 98(5): 1978-97.

Helpman, E., 2006. Trade, FDI, and the organization of firms. Journal of Economic Literature, 44, 589-630.

Hennart, J.-F. 1982. A theory of multinational enterprise. Ann Arbor, MI: University of Michigan Press.

Hennart, J.-F. 2009. Down with MNE-centric theories! Market entry and expansion as the bundling of MNE and local assets. Journal of International Business Studies, 40: 1432-1454. 
Hipple, F. S. 1990. The measurement of international trade related to multinational companies. American Economic Review, 80(5): 1263-1270.

Hitt, L. 1999. Information technology and firm boundaries: evidence from panel data. Information Systems Research, 10(2): 134-149.

Hong, W. \& Zhou, K., 2006. Migrating to internet-based e-commerce: Factors affecting e-commerce adoption and migration at the firm level, Information and Management, 43: 204-221.

Jarmin, R. S., \& Miranda, J. 2002. The longitudinal business database. Working Papers 02-17, Center for Economic Studies, U.S. Census Bureau.

Keane, M. P. \& Feinberg, S.E. 2007. Advances in logistics and the growth of intra-firm trade: The case of Canadian affiliates of U.S. multinationals, 1984-1995. Journal of Industrial Economics, 55(4): 571-632.

Kim J. \& Mahoney J.T. 2005. Property rights theory, transaction costs theory, and agency theory: an organizational economics approach to strategic management. Managerial and Decision Economics, 26(5): 489-496.

Kim, S. M. \& Mahoney, J. T. 2006. Mutual commitment to support exchange: Relation-specific IT system as a substitute for managerial hierarchy. Strategic Management Journal, 24: 401-423.

Kohler, W. 2004. International outsourcing and factor prices with multistage production. The Economic Journal, 494: C 166-C185.

Malone, T.W., Yates, J., \& Benjamin, R.I. 1987. Electronic markets and electronic hierarchies. Communications of the ACM 30(6): 484-497.

McPhee, R., \& Poole, M.S. 2001. Organizational structures and configurations. In F. M. Jablin, \& L.L. Putnam (Eds), The New Handbook of Organizational Communication: Advances in Theory, Research, and Methods: 503-543. Thousand Oaks, CA: Sage.

Messenbourg, T. 2001. Measuring electronic business definitions, underlying concepts, and measurement plans. U.S. Census Bureau. http://www.census.gov/econ/estats/papers/ebusasa.pdf.

McElheran, Kristina, 2015. Do market leaders lead in business process inovation? The case(s) of ebusiness adoption, Management Science, 61(6): 1197-1216.

Nunn, T., \& Trefler, D. 2013. Incomplete contracts and boundaries of the multinational firm. Journal of Economic Behavior and Organization, 94: 330-344.

Rangan, S., \& Sengul, M. 2009. Information technology and transnational integration: Theory \& evidence on the evolution of modern multinational enterprise. Journal of International Business Studies, 40(9): 1496-1514.

Rice, R.E., \& Gattiker, U.E. 2001. New media and organizational structuring. In F. M. Jablin, \& L.L. Putnam (Eds), The New Handbook of Organizational Communication: Advances in Theory, Research, and Methods: 544-581. Thousand Oaks, CA: Sage.

Ruhl, K. J. 2013. An Overview of U.S. Intrafirm-Trade Data Sources. Mimeo. 
Sturgeon, T. J. 2002. Modular production networks: a new American model of industrial organization. Industrial and Corporate Change, 11(3): 451-496.

Teece, D. J. 1986. Transactions Cost Economics and the Multinational Enterprise. Journal of Economic Behavior and Organization, 7: 21-45.

UNCTAD. 2013. World Investment Report. http://unctad.org/en/pages/PressRelease.aspx?OriginalVersionID=113. Accessed 13 August 2014.

U.S. Census Bureau. 1999. U.S. Manufacturers’ Value of Shipments. http://www.census.gov//econ/estats/1999/manu_initial/MCDtables.pdf. Accessed 13 August 2014.

U.S. Census Bureau. 2014. Imports and Exports by Related Parties. http://www.census.gov/foreigntrade/Press-Release/related_party/. Accessed 13 August, 2014.

Worthen, B. 2002. Nestlé’s ERP Odyssey. CIO Magazine, 62-70.

World Development Indicators, The World Bank. http://data.worldbank.org/data-catalog/worlddevelopment-indicators.

Zeile, W. J., 2003. Trade in goods with multinational companies: Survey-based data and findings for the United States of America. http://www.bea.gov/papers/pdf/IFT OECD Zeile.pdf.

Zenger, T. R., \& Hesterly, W. S. 1997. The disaggregation of corporations: Selective intervention, high- powered incentives, and molecular units. Organization Science, 8: 209-222. 
Table 1. Summary Statistics, 1992 and 1999

\begin{tabular}{|c|c|c|c|}
\hline \multirow[t]{2}{*}{ Variable Name } & \multirow[t]{2}{*}{ Variable Description } & \multicolumn{2}{|c|}{$\begin{array}{c}\text { Mean } \\
\text { (standard deviation) }\end{array}$} \\
\hline & & 1992 & 1999 \\
\hline ICT & $\begin{array}{l}1 \text { if a firm adopts an internet-enabled computer network } \\
0 \text { otherwise }\end{array}$ & NA & $\begin{array}{c}0.666 \\
(0.323)\end{array}$ \\
\hline $\begin{array}{l}\text { Types of ICT } \\
-\quad \text { Internet }\end{array}$ & $\begin{array}{l}1 \text { if a firm adopts internet } \\
0 \text { otherwise }\end{array}$ & NA & $\begin{array}{c}0.574 \\
(0.367)\end{array}$ \\
\hline - E-commerce applications & $\begin{array}{l}1 \text { if a firm adopts LAN, intranet, or extranet } \\
0 \text { otherwise }\end{array}$ & NA & $\begin{array}{c}0.852 \\
(0.355)\end{array}$ \\
\hline Intra-firm Trade Share & Intra-Firm (Exports + Imports)/Total Trade & $\begin{array}{c}0.133 \\
(0.239)\end{array}$ & $\begin{array}{c}0.143 \\
(0.237)\end{array}$ \\
\hline Intra-firm Export Share & Intra-Firm Exports/Total Trade & $\begin{array}{c}0.072 \\
(0.158)\end{array}$ & $\begin{array}{c}0.074 \\
(0.149)\end{array}$ \\
\hline Intra-firm Import Share & Intra-Firm Imports/Total Trade & $\begin{array}{c}0.061 \\
(0.166)\end{array}$ & $\begin{array}{c}0.070 \\
(0.169)\end{array}$ \\
\hline Initial Age & Firm Age as of 1992 & $\begin{array}{l}12.568 \\
(5.551)\end{array}$ & NA \\
\hline Labor Productivity & Total Value of Shipments/Total Employment & $\begin{array}{c}159.041 \\
(214.421)\end{array}$ & $\begin{array}{c}224.45 \\
(236.553) \\
\end{array}$ \\
\hline Observations & & 5,850 & 5,850 \\
\hline
\end{tabular}


Table 2. Correlation matrix, 1992 and 1999.

\begin{tabular}{|c|c|c|c|c|c|c|}
\hline Variable & (1) & $(2)$ & (3) & (4) & (5) & (6) \\
\hline 1. Change in Intra-firm Trade Share & 1.00 & - & - & - & - & - \\
\hline 2. Change in ICT & 0.035 & 1.00 & - & - & - & - \\
\hline 3. Change in Internet & 0.029 & 0.868 & 1.00 & - & - & - \\
\hline 4. Change in E-commerce applications & 0.038 & 0.739 & 0.619 & 1.00 & - & - \\
\hline 5. Initial Age & $-0.022^{\dagger}$ & $0.016^{\dagger \dagger}$ & $0.010^{\S}$ & $-0.018^{\dagger}$ & 1.00 & - \\
\hline 6. Change in Labor Productivity & 0.049 & 0.088 & 0.085 & 0.136 & $-0.019^{\dagger}$ & 1.00 \\
\hline Observations & & & 11,700 & & & \\
\hline
\end{tabular}


Table 3. Difference-in-differences regressions explaining intra-firm trade shares: The role of ICT. Variable (1) (2) (3)

ICT

$0.018 * *$

(0.006)

Types of ICT

- Internet

$0.026 * *$

(0.005)

- E-commerce applications

$0.032 * * *$

(0.005)

Initial Age

$-1.030^{*}$

$(0.000)$

$-0.022 *$

$-0.021 *$

$0.033 * *$

(0.000)

(0.000)

Labor Productivity

(0.000)

$0.046^{* *}$

$0.044 * *$

11,700

(0.000)

(0.000)

Observations

11,700

11,700

Notes: Significance level: $\dagger$ if $\mathrm{p}<0.10, *$ if $\mathrm{p}<0.05$; ** if $\mathrm{p}<0.01 ; * * *$ if $\mathrm{p}<0.001$. Robust standard errors in parentheses. All regressions are estimated in first differences; initial age included in levels. Columns (2) and (3) report beta coefficients. Age and Labor Productivity coefficients multiplied by 1,000 for ease of interpretation. Number of observations rounded to the nearest integer for disclosure avoidance. 
Table 4. Difference-in-differences regressions explaining intra-firm trade shares: The role of ICT and industry electronic codifiability.

\begin{tabular}{lc}
\hline Variable & $(1)$ \\
\hline ICT & $0.021^{* * *}$ \\
& $(0.007)$ \\
ICT * Codifiability & $-0.002 \dagger$ \\
& $(0.001)$ \\
Initial Age & -0.066 \\
& $(0.000)$ \\
Labor Productivity & $0.033^{* *}$ \\
& $(0.000)$
\end{tabular}

Observations

11,640

Notes: Significance level: $\dagger$ if $\mathrm{p}<0.10, *$ if $\mathrm{p}<0.05 ; * *$ if $\mathrm{p}<0.01$; *** if $\mathrm{p}$ $<0.001$. Robust standard errors in parentheses. All regressions are estimated in first differences; initial age included in levels. "Codifiability" is measured as the share of plants that use CAD/CAE technology in a six-digit NAICS industry. Age and Labor Productivity coefficients multiplied by 1,000 for ease of interpretation. Number of observations rounded to the nearest integer for disclosure avoidance. 


\section{Endnotes}

${ }^{1}$ References to specific companies in the text are based on public information.

${ }^{2}$ Although we cannot distinguish between U.S. and foreign MNEs in the trade transactions data, about $70 \%$ (60\%) of intra-firm exports (imports) are between U.S. parents (foreign parents) and their foreign affiliates (U.S. affiliates) in 1992 and 1999 (Zeile, 2003). 